\title{
生态系统服务净价值核算方法及其对北京市人工林项目 的评估
}

\author{
${\text { 曹世雄 }{ }^{(1 *} \text {, 李宇腾 }{ }^{(1)} \text {, 鲁晨曦 }}^{(2)}$ \\ (1) 北京林业大学经济管理学院, 北京 100083; \\ (2) 清华大学地球系统与科学研究中心, 北京 100084 \\ * 联系人, E-mail: shixiongcao@126.com
}

2016-01-08 收稿, 2016-06-03 修回, 2016-06-06 接受, 2016-07-12 网络版发表

国家重点研发计划(2016YFC0501002)资助

\begin{abstract}
摘要生态系统服务价值评估是评价自然生态系统和人工生态系统经济价值的重要方法, 是生态学和地理学研 究的重要领域. 然而, 任何价值的形成都免不了成本投入，学术界普遍使用的生态系统服务价值评估方法忽略了 生态系统在形成这些服务功能时的成本投入(包括直接投入成本、资源占用成本、风险成本等)，计算得出的服务 价值必然会夸大自然和人工生态系统、以及维护和恢复生态系统相关措施的经济学意义，给土地利用规划造成混 乱, 影响了国民经济发展规划的科学性和可行性. 为了探索基于可持续发展目标的土地规划的有效方法, 该研究 在生态系统服务价值概念的基础上，提出了生态系统服务净价值评估方法，并以北京市人工林项目为例，解释了 这一方法的应用原理及其意义。通过生态系统服务净价值评估，可以比较分析不同土地利用方式产生的最大净收 益，为土地的资源化利用、工农业项目、以及生态环保项目的科学规划和评估提供决策依据，并为社会经济可持 续发展、以及国民经济发展规划提供科学依据.
\end{abstract}

关键词生态系统服务价值，土地规划，生态系统服务净价值(NES)，机会成本，风险成本

环境保护和土地利用规划应该致力于实现生态 平衡与社会发展双重目标、而不是某个单一目标，这 是全球千年生态计划的核心思想 ${ }^{[1,2]}$. 在土地利用规 划时，从生态经济学角度评估各种土地规划项目的 成本与收益, 明确土地利用的资源与环境成本、及其 潜在效果是必要的. 目前最为流行的对资源与环境 成本付费方式是“生态补偿 (payment for ecosystem services，PES)”方法，该方法可以较好地对资源短缺 和环境退化发出的预警信号, 从而达到提高生态系 统服务价值、强化环境保护的目的.“生态补偿”理论 可促使土地管理者修改土地规划方案、减轻甚至避免 环境问题的出现 ${ }^{[3,4]}$. 正如 Costanza等人 ${ }^{[5]}$ 强调的那
样, 自然资源只能通过它和人类的相互作用, 并通过 生态系统服务方式，才能给人类社会提供资源价值, 体现其本身的资本意义.

因此，最佳的土地利方式必须鼓励管理者了解 土地的交易成本、生态系统服务价值等一系列潜在成 本与收益、及其形成的原因, 这样才能实现社会利益 最大化 ${ }^{[6,7]}$. 然而, 早期的生态系统服务价值估算方 法侧重于收益部分, 成本评估停留在直接成本, 忽略 了间接成本 ${ }^{[8]}$. 在国内, 一些自然学科的学者甚至完 全没有成本这个概念 ${ }^{[9]}$. 这样虽然不影响相关个人与 社会选择 ${ }^{[10]}$, 但因为管理决策的不完整, 导致决策 失灵, 并制约未来社会的可持续发展 ${ }^{[11]}$. 从理论上 
讲, 设计出一个有效的环境保护和社会经济发展的 政策、并实现所有利益相关者的利益最大化, 无疑是 最佳结果; 然而, 实施这样的计划成本巨大 (例如, 全球每年仅用于保护鸟类繁殖聚居地的耗费就高达 651 亿美元), 其潜在影响目前尚不清楚 ${ }^{[4]}$.

从局部到全球范围的长期利益来看, 环境改善 (如水质改善、水土流失的有效控制、减少温室气体 排放等等) 会给社会带来长期的净收益 ${ }^{[9]}$. 然而, 从 短期和局部区域角度来看, 环境保护对项目区域居 民的成本投人是巨大的. 因此, 可持续的土地利用必 须同时考虑当前和未来、局部与整体利益, 实现社会 净收益的最大化 ${ }^{[10,12]}$. 为了实现这一目标, 土地规划 必须全盘考虑各种方案的成本与收益, 为论理决策 与行动提供科学依据 ${ }^{[11]}$. 每年全球生态保护项目的 耗费巨大 ${ }^{[13]}$, 因此, 如何甄别环保项目的净收益是 十分重要的 ${ }^{[14]}$. 为了满足以上要求, 必须提出估算 生态系统服务净价值(NES)的有效方法, 评估不同土 地利用规划和变化的结果, 为土地规划提供更加精 确可靠的依据.

为了实现这一目标, 本研究提出了一个生态系 统服务净价值评估模型, 用于评估不同的土地利用 方式或者不同的土地管理项目的生态系统服务净价 值的变化, 为土地优化利用提供决策依据. 为了使这 一方法便于理解, 该研究通过北京市造林项目的再 评估, 解析相关模型的应用.

\section{1 生态系统服务净价值评估方法的理论 框架}

任何价值的形成都免不了成本投人, 因此, 认识 生态系统为人类提供服务的成本是必要的. 在既定 条件下, 估算生态系统服务的价值 $(S)$ 时, 不能忽略 相关成本 $(C)$. 在此基础上, 该研究定义生态系统服 务的净价值 (net value of ecosystem services, NES)为 考虑了所有成本后的净值:

$$
\mathrm{NES}=S-C,
$$

式中, $S$ 是生态系统服务价值, 包括直接产出 (如土地 产出的农产品、或者土地用于替代项目后的产品收 益)、以及提供的各种生态服务 (如净化空气、保持水 土、减少污染等)的价值. 因为生态系统服务价值计 算已经应用了近 20年了, 所以我们的模型模拟计算 时忽略了这一部分的计算过程, 相关项目的生态系 统服务价值直接从引用的参考文献中引人; $C$ 是形成
生态系统服务价值的成本，包括投资在生态修复和 环境保护项目中的直接成本或者土地用于替代项目 时的投人预算 $\left(C_{\mathrm{d}}\right)$ 、资源占用的机会成本 $\left(C_{\mathrm{o}}\right)$, 以及 其他风险成本 $\left(C_{\mathrm{r}}\right)$ (包括维护生态与社会经济安全的 各种风险等等):

$$
C=C_{\mathrm{d}}+C_{\mathrm{o}}+C_{\mathrm{r}},
$$

直接成本 $\left(C_{\mathrm{d}}\right)$ 可以从项目规划和土地管理者的预算 报告中获得. 机会成本 $\left(C_{\mathrm{o}}\right)$ 是指资源投资在替代项目 时可能获得的最大净利润. 为了简化该案例分析计 算, 该研究假设人工造林工程的机会成本 $\left(C_{\mathrm{o}}\right)$ 为占用 土地 $\left(C_{\mathrm{i}}\right)$ 和水 $\left(C_{\mathrm{w}}\right)$ 资源在其他用途上产生的收益或者 产生的价值. 具体来说, 该研究把土地的机会成本视 为进行替代产业的净产出或者用于其他行业的租赁 费用、水资源的机会成本为水的市场价值或者影子价 格(如南水北调工程的水价格为 1.2 元 $\left./ \mathrm{m}^{3}\right)^{[15]}$. 农田灌 溉有一部分水是补给地下的, 所以从生态学的角度 来看, 耗水量仅考虑蒸散发耗水就可以了:

$$
C_{\mathrm{o}}=C_{\mathrm{i}}+C_{\mathrm{w}},
$$

该研究定义风险成本 $\left(C_{\mathrm{r}}\right)$ 为事故之后必需的支出. 在 该研究的案例分析中, 风险主要指自然灾害, 包括植 物病虫害 $\left(C_{\mathrm{p}}\right)$ 和火灾 $\left(C_{\mathrm{f}}\right)$ :

$$
C_{\mathrm{r}}=C_{\mathrm{p}}+C_{\mathrm{f}} .
$$

为了比较在人工造林政策和替代土地利用方式 下的NES, 本研究从已发表的论文中获得了生态系

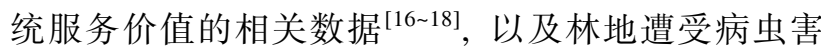
的损失 ${ }^{[19,20]}$ 、火灾的损失 ${ }^{[21]}$ 等. 以上的模型忽略了自 然环境利用的时间和空间变化的影响、以及生物演化 过程的潜在收益, 这部分工作需要在今后的研究中 做进一步完善.

为了理解NES对生态系统管理、环境保护、土地利 用规划、以及环境政策中的影响, 该研究选择了北京市 造林项目作为研究按案例, 模拟比较人工造林项目区 域的NES与可替代的生态修复项目(例如自然修复、农 田生态系统管理)的NES，比较NES和PES在土地利用 规划应用方面的差异与优劣. 北京市的平原造林是对 生态系统服务价值评估方法错误应用的典型例证，相 关例证分析可以更加突出该方法的实用价值.

\section{2 北京市人工林项目的生态服务净价值评估}

北京市位于北纬 $39^{\circ} 56^{\prime}$ 、东经 $116^{\circ} 20^{\prime}$ ，面积 1.68 万 $\mathrm{km}^{2}$, 人口 2152 万, 年均气温 $10 \sim 12^{\circ} \mathrm{C}$, 年均降水 $545 \mathrm{~mm}$ ，森林覆盖率 $40.1 \%$. 作为中国首都，北京市 
是国家政治文化中心. 2014 年, 北京市人均耕地 0.16 亩 $\left(1\right.$ 亩 $=666.6666667 \mathrm{~m}^{2}$ )、人均GDP 10万元、人均财 政收人 1.9 万元, 分别是全国平均水平的 $0.12,2.1$ 和 19 倍, 是北京市 1978 年的 $0.4,79.6$ 和15.3倍. 与全国北 方城市一样, 这里饱受水资源短缺、环境污染、沙尘 暴等环境问题的困扰. 为了有效应对沙尘暴的危害, 2000年以来中央政府累积投资 600 亿元, 开展了京津 唐防沙固沙造林工程, 在北京及其周边地区完成人 工造林 520 万公顷; 为了改善北京郊区景观状态、降 低空气中 $\mathrm{PM}_{2.5}$ 含量, 2012 年北京市政府投资 180 亿元, 在城市周边的平原地区启动了北京市平原造林工程, 投资强度高达每公顷 45 万元, 3 年每年完成人工造林 4 万公顷 ${ }^{[22]}$. 与其他绿色工程相比, 平原造林工程有 以下 3 个特点: (1) 项目区为平原灌溉农业区, 补偿农 民的农业损失成本很高; (2) 除了森林生态效益, 项 目会大幅度改变当地景观与土地用途, 需要各种景 观树种和较高的造林管理技术, 人工造林成本高; (3) 因为必须进行园林管护才能获得预期效果, 管理成 本也很高 ${ }^{[22]}$. 从传统的生态系统服务价值来看, 如果 不考虑投资成本和土地利用方式改变的机会成本, 这 些工程意义巨大. 那么考虑到资金投人、资源占用, 这 种土地利用方式的改变是否更加经济? 生态服务净价 值评估方法可以比较好地给出结果.

\section{1 北京市平原林项目生态服务净价值评估}

生态系统服务净价值评估结果表明, 平原造林 项目的生态系统服务价值每公顷每年高达 6.5 万 元 $^{[15 ~ 23]}$, 比农田种植高 $10.8 \%$; 考虑成本后, 平原地 区农田转化为人工林地的生态系统服务净价值每公 顷每年为 -2.13 万元, 相比该区域农田时净收益为每 公顷每年 3.43 万元, 农田转化为林地的单位面积生态 系统服务价值净损失高达 5.56 万元/ha(表 1$)$.

\section{2 北京市防护林生态服务净价值的评估}

研究结果表明, 由于防护林不能砍伐, 其生态系 统服务价值与天然林相近，在考虑成本后的山区人 工造林区的生态系统服务净价值为每公顷每年-1.22 万元, 单位面积比自然修复减少 1.25 万元 $/ \mathrm{ha}($ 表 2$)$.

\section{3 讨论与建议}

人类主导的土地利用变化是自然环境和整个生 态系统服务供应变化的主要驱动因素 ${ }^{[10]}$, 占植被变 化的 $60 \%$ 以上 ${ }^{[24]}$. 天然草原、林地、湿地逐渐转变成 农田, 人工生态系统扩大极大地增加了食物、木材、 以及其他产品的供给, 同时减少了生物多样性和其 他生态系统的服务价值 ${ }^{[25]}$. 由此可见, 任何土地利 用的选择都面临潜在的机会成本问题，当计算这些 机会成本时, 收益与成本之间的差异就会发生变 化 ${ }^{[26]}$. 正如以上北京市造林项目的评估结果, 考虑 机会成本的NES方法和不考虑机会成本的PES方法 在土地利用规划应用方面存在显著差异. 由此可见, NES 和PES在土地利用规划应用方面的差异非常显 著, 用传统的PES评估方法, 北京市平原人工造林似 乎比农业生产合算; 然而, NES的评价结果正好相 反. 用可替代的土地利用方式进行测算分析, 可以清 晰地证明将成本考虑在生态系统服务价值中的重 要性.

对于整个自然和社会来说，生态成本受许多因 素的影响, 这增加了估算生态系统服务净价值的难 度. 因为NES会随时间和空间变化而变化, 所以该方 法涉及的空间精确度需要在未来研究中得到解决. 随着市场发展，市场扩大也会影响价格，而市场价格 是经济发展、社会进步、以及环境条件变化的反馈 ${ }^{[1]}$, 它们之间的关系是动态的、并且随时间变化而变 化 ${ }^{[27 ~ 29]}$. 未来粮食价格、气候和其他因素的变化, 将

表 1 北京市造林与农作方式的生态系统服务净价值比较分析 ${ }^{\mathrm{a}}$

Table 1 Comparison of NES value for different land uses in Beijing City, China (based on published data)

\begin{tabular}{|c|c|c|c|c|c|c|c|c|}
\hline & \multirow{3}{*}{$\begin{array}{l}\text { 生态服务价值 } \\
\left(\times 10^{3} \mathrm{RMB} / \mathrm{ha}\right)\end{array}$} & \multicolumn{6}{|c|}{ 年均成本 $\left(\times 10^{3} \mathrm{RMB} / \mathrm{ha}\right)$} & \multirow{3}{*}{$\begin{array}{c}\text { NES } \\
\left(\times 10^{3} \mathrm{RMB} / \mathrm{ha}\right)\end{array}$} \\
\hline & & \multicolumn{2}{|c|}{ 直接投入 $\left(C_{\mathrm{d}}\right)$} & \multicolumn{2}{|c|}{ 机会成本 $\left(C_{\mathrm{o}}\right)$} & \multicolumn{2}{|c|}{ 风险成本 $\left(C_{\mathrm{r}}\right)$} & \\
\hline & & 投资 & 管理 & 耗水 & 用地 & 病虫害 & 火灾 & \\
\hline 平原造林 & 65.24 & 64.83 & 3.50 & 7.33 & 14.25 & 0.09 & 0.02 & -21.28 \\
\hline 农田 & 58.89 & 0.00 & 4.54 & 4.03 & 14.25 & 1.72 & 0.01 & 34.34 \\
\hline 差异 & 6.35 & 64.83 & -1.04 & 3.3 & 0 & -1.63 & 0.01 & -55.62 \\
\hline
\end{tabular}

a) 投资按30年周期核算，年贴现回报率 $0.5 \%$; 生态系统服务价值包括木材、农产品、以及美观、净化空气等等所有服务品的收益; 管理成本主要指化肥、农具、基础设施维修、收获等成本; 生态系统服务价值和各种成本的数据来源于文献[15 23]的研究结果 
表 2 北京市生态林建设与天然林地的生态系统服务净价值比较分析 ${ }^{\mathrm{a})}$

Table 2 Comparison of NES value for different land uses of ecological conservation in Beijing City, China (based on published data)

\begin{tabular}{|c|c|c|c|c|c|c|c|c|}
\hline & \multicolumn{7}{|c|}{ 年均成本 $\left(\times 10^{3} \mathrm{RMB} / \mathrm{ha}\right)$} & \multirow{3}{*}{$\begin{array}{c}\mathrm{NES} \\
\left(\times 10^{3} \mathrm{RMB} / \mathrm{ha}\right)\end{array}$} \\
\hline & \multirow{2}{*}{$\begin{array}{l}\text { 生态服务价值 } \\
\left(\times 10^{3} \mathrm{RMB} / \mathrm{ha}\right)\end{array}$} & \multicolumn{2}{|c|}{ 直接投人 $\left(C_{\mathrm{d}}\right)$} & \multicolumn{2}{|c|}{ 机会成本 $\left(C_{\mathrm{o}}\right)$} & \multicolumn{2}{|c|}{ 风险成本 $\left(C_{\mathrm{r}}\right)$} & \\
\hline & & 投资 & 管理 & 耗水 & 用地 & 病虫害 & 火灾 & \\
\hline 山地造林 & 6.28 & 10.81 & 0.15 & 7.33 & 0.05 & 0.09 & 0.02 & -12.17 \\
\hline 天然林地 & 6.28 & 0.00 & 0.15 & 5.62 & 0.05 & 0.09 & 0.02 & 0.35 \\
\hline 差异 & 0 & 10.81 & 0 & 1.71 & 0 & 0 & 0 & -12.52 \\
\hline
\end{tabular}

a) 因为生态林禁止采伐, 所以服务价值不包括木材产出. 耗水量用蒸散发模型估算, 数值来源于文献[23], 天然林指的是通过自 然修复形成的次森林

对土地利用预测产生极大影响. 政策变化也会直接影 响土地利用规划的评价结果, 比如过去政策鼓励林木 采伐, 人工造林的生态服务净价值很高; 现在禁止采 伐, 人工林的收益就很难弥补造林的投人成本了(表2).

科学合理的土地规划是基于长期(比如以上计算 的30年) 土地净收益最大化的综合结果, 而不是追求 某个单一指标 (比如森林覆盖度) 的最大化和短期 利益的最大化 ${ }^{[30]}$. 不同地区不仅存在地理和气候差 异, 自然资源的稀缺程度也不同, 资源的价格也不 同, 因此, NES方法评估的结果会有很大差异. 由此 可见, 在进行较大范围区域的土地政策调整和相关 大型项目规划时, 资源价格会受区域价格变化差异 的影响; 同时, 一般项目都有较长时间的运营时间, 时间变化也会影响资源的市场价格. 因此, 在应用该 模型时, 资源的动态价格预测是必要的. 区域之间的 资源静态价格可以通过对不同地区实际价格的调查 获得, 动态价格可以通过相关情景模拟获得, 也可以 用资源稀缺性模型进行模拟 ${ }^{[23]}$. 应用资源稀缺价格 模型模拟各个地区各个资源的机会成本可大大地提 高NES方法的使用效率.

尽管以前的学者在资源稀缺性模型上做了大量 研究, 但资源的价格决定也受非市场因素(如政策变 化)的影响 ${ }^{[23]}$, 在应用该模型时需要依据相关项目的
实际情况对模型进行改进. 为了促进NES方法的应 用，土地管理者、政策制定者、以及科学家们应改协 同研究，积极应对上述问题. 考虑到预测气候变化的 复杂性和地方、区域、全球尺度下影响生态系统服务 的诸多因素，管理者必须努力鉴定和量化各个关键 因素, 在生态和社会效益中进行权衡, 尤其是要在短 期收益和长期收益中进行权衡, 为NES方法提供包 含更多因素的模型以及应用更加可靠和精确的数据.

\section{4 结束语}

$\mathrm{NES}$ 土地规划评价方法, 能够把生态环境保护 与社会经济发展的其他项目统一起来, 通过明确的 净价值评估对土地变化的各种方案进行比对. 虽然 不同项目计算方法的基本原理是相通的，比如大坝 建设要考虑他的所有经济和生态产出, 然后减去项 目建设占用的资源的成本、风险成本以及建设与运营 成本. 作为一个初始的方法论探索, 必须是简化的理 想状态, 如果过于复杂, 就起不到抛砖引玉的作用 了. 因此, 对于更加复杂的方法, 比如加人市场变 化、气候变化、社会变化等因素的复杂模型, 以及应 用于更加复杂的工农业土地规划领域，均可在这一 模型基础上进行改进. 这是今后这一领域研究的重 要方向.

\section{参考文献}

1 Tallis H, Kareiva P, Marvier M, et al. An ecosystem services framework to support both practical conservation and economic development. Proc Natl Acad Sci USA, 2008, 105: 9457-9464

2 Zheng H, Wang G. Achieving ecological restoration by working with local people: A Chinese scholar seeks win-win paths. Ecol Soc, 2014, 19: 35

3 Kinzig A, Perrings C, Chapin F, et al. Paying for ecosystem services-promise and peril. Science, 2011, 334: 603-604

4 McCarthy D, Donald P, Scharlemann J, et al. Financial costs of meeting global biodiversity conservation targets: Current spending and unmet needs. Science, 2012, 338: 946-949

5 Costanza R, de Groot R, Sutton P, et al. Changes in the global value of ecosystem services. Glob Environ Change, 2014, 26: 152-158 
6 Bateman I, Harwood A, Mace G, et al. Bringing ecosystem services into economic decision-making: Land use in the United Kingdom. Science, 2013, 341: 45-50

7 Polasky S, Lewis D, Planting A, et al. Implementing the optimal provision of ecosystem services. Proc Natl Acad Sci USA, 2014, 111: 6248-6253

8 Naidoo R, Ricketts T. Mapping the economic costs and benefits of conservation. PLoS Biol, 2006, 4: e360

9 Li C, Zheng H, Li S, et al. Impacts of conservation and human development policy across stakeholders and scales. Proc Natl Acad Sci USA, 2015, 112: 7396-7401

10 Tilman D, Cassman K, Matson P. Agricultural sustainability and intensive production practices. Nature, 2002, 418: 671-677

11 Daily G, Ouyang Z, Zheng H, et al. Securing natural capital and human well-being: innovation and impact in China. Acta Ecol Sin, 2013, 33: 677-685

12 Zheng H, Robinson B, Liang Y, et al. Benefits, costs, and livelihood implications of a regional payment for ecosystem service program. Proc Natl Acad Sci USA, 2013, 110: 16681-16686

13 Goldstein J, Pejchar L, Daily G. Using return-on-investment to guide restoration: A case study from Hawaii. Conserv Lett, 2008, 1: 236-243

14 Chen Z, Chen G, Chen B, et al. Net ecosystem services value of wetland: Environmental economic account. Commun Nonlinear Sci Numer Simulat, 2009, 14: 2837-2843

15 Liu J, Yang W. Water sustainability for China and beyond. Science, 2012, 337: 649-650

16 Costanza R, Arge R, Groot R, et al. The value of the world's ecosystem services and natural capital. Nature, 1997, 387: 253-260

17 Xiao Y, Xie G D, An K, et al. Ecosystem services of wheat-maize cropland systems in the North China Plain (in Chinese). Chin J Eco-Agric, 2011, 19: 429-435 [肖玉, 谢高地, 安凯, 等. 华北平原小麦-玉米农田生态系统服务评价. 中国生态农业学报, 2011, 19: 429-435]

18 Lei N, Zhang Y Q, Wu B, et al. The farm shelter-forests ecosystem services valuation in Huang-Huai-Hai Plain (in Chinese). Heilongjiang Agric Sci, 2011, 7: 82-85 [雷娜, 张宇清, 吴斌, 等. 黄淮海平原农田防护林生态服务价值研究. 黑龙江农业科学, 2011, 7: $82-85$

19 Lü W, Hu M, Hu J J, et al. Discussion on severity and control of Asian longhorned beetle of poplar trees in the Three Norths Protection Forest Program (in Chinese). For Sci Tech, 2004, 58: 39-41 [吕文, 胡莽, 胡建军, 等. 三北防护林杨树天牛的危害与防治. 防护林 科技, 2004, 58: 39-41]

20 Jiang Y Y, Zeng J, Lu M H, et al. Occurrence trend forecast of major diseases and insect pests of main crops in China in 2014 (in Chinese). Plant Protect, 2014, 40: 1-4 [姜玉英, 曾娟, 陆明红, 等. 2014 年全国主要粮食作物重大病虫害发生趋势预报. 植物保护, 2014, 40: 1-4]

21 Tian G H, Yang S. Characteristic of forest fire in 31 provinces in China. For Prev, 2013, 2: 10-14 [田国华, 杨松. 我国 31 个地区森林 火灾时空分布特征. 森林防火, 2013, 2: 10-14]

22 Qiao Y Q, Wang J Z, Li J. The summary and reflection of Beijing's plain reforestation-taking Qingyundian of Daxing District as an example (in Chinese). For Econ, 2014, 4: 17-19 [乔永强, 王金增, 李静. 北京平原造林工程实施成效总结与反思一以大兴区青云店 平原造林工程为例. 林业经济, 2014, 4: 17-19]

23 Zhang J, Zhao T, Jiang C, et al. Opportunity cost of water allocation to afforestation rather than conservation of natural vegetation in China. Land Use Policy, 2016, 50: 67-73

24 Cao S, Ma H, Yuan W, et al. Interaction of ecological and social factors affects vegetation recovery in China. Biol Conserv, 2014, 180: 270-277

25 Lawler J J, Lewis D J, Nelson E, et al. Projected land-use change impacts on ecosystem services in the United States. Proc Natl Acad Sci USA, 2014, 111: 7492-7497

26 Mittermeier R, Mittermeier C G, Brooks T M P, et al. Wilderness and biodiversity conservation. Proc Natl Acad Sci USA, 2003, 100: 10309-10313

27 Birch J C, Newton A C, Aquino C A, et al. Cost-effectiveness of dry-land forest restoration evaluated by spatial analysis of ecosystem services. Proc Natl Acad Sci USA, 2010, 107: 21925-21930

28 Corbera E, Pascual U. Ecosystem services: Heed social goals. Science, 2012, 335: 655-656

29 Jack B K, Kousky C, Sims K. Designing payments for ecosystem services: Lessons from previous experience with incentive-based mechanisms. Proc Natl Acad Sci USA, 2008, 105: 9465-9470

30 Foley J A, DeFries R, Asner G P, et al. Global consequences of land use. Science, 2005, 309: 570-574 


\title{
A measure of the net value of ecosystem services and the evaluation of Beijing Plain Afforestation Project
}

\author{
CAO ShiXiong ${ }^{1}$, LI YuTeng ${ }^{1} \&$ LU ChenXi $^{2}$ \\ ${ }^{1}$ School of Economics and Management, Beijing Forestry University, Beijing 100083, China; \\ ${ }^{2}$ Center for Earth System Science, Tsinghua University, Beijing 100084, China
}

Landscapes generate a wide range of valuable ecosystem services, and valuation of these services provides support for land-use decisions. The most common approach to identifying these tradeoffs is called "payment for ecosystem services" (PES), and when this approach is carefully applied, it has the potential to enhance how ecosystem services are used and improve their protection by signaling the development of a scarcity of environmental resources. However, this approach often ignores the opportunity costs of these services, thereby making the net benefit of the ecosystem services and their responses to land-use change unclear. Therefore, there must be a fuller accounting for both the costs and the benefits of various alternatives, and such an accounting must become the basis for developing policy, reaching ethical decisions, and taking appropriate actions. Through the evaluation of net value of ecosystem services, we can compare the maximum net benefits of alternative land uses, thereby providing basis for decision-making during land use planning, industrial and agricultural programs and ecological and environmental restoration programs as well as socioeconomic and national economic development planning.

To address this need, a new approach based on determining the net value of ecosystem services (NES) should be developed to provide a more rigorous comparison of the consequences of land-use change. This approach reveals large differences between the values of a given land use when opportunity costs are and are not accounted for. To illustrate the new approach, here, we use the example of the Beijing Plains Afforestation Project to illustrate the benefits of accounting for the direct and opportunity costs of alternative land uses based on changes in ecosystem services, thereby determining the net value of these services and providing better support for land-use planning and policy development. For this project, we calculated the NES resulting from ecological restoration by comparing the current program of restoration via afforestation with alternatives such as restoration based on the conservation of natural vegetation and management of a farmland ecosystem.

The results shows that the ecosystem service values of creating a large-scale artificial forest ecosystem through afforestation may be strongly negative in the short run when we account for the opportunity costs of this strategy. Evaluating the long-term effects is currently not possible, as this will require data from monitoring the afforestation project to determine how the ecosystem services values provided by the artificial forest evolve over time. Therefore, the results of such approaches absolutely will exaggerate the value of natural and artificial ecosystem as well as the economic significance of related measures to maintain and restore the ecosystem and will cause the disruption of the land use planning, affecting the scientific and feasible planning of national economic development.

Given the complexity of predicted future climate change and the wide range of landscape-, regional-, and global-scale factors that affect ecosystem services, managers must work harder to identify and quantify the tradeoffs among ecological and socioeconomic benefits, and particularly the trade-offs between short-term benefits (which often drive political decisions) and long-term benefits (which determine the sustainability of human civilization). The challenges for future research will be to account for the problems described in this paper, particularly in terms of the trade-offs among competing objectives, identifying and quantifying opportunity costs for all stakeholders, and providing improved versions of the NES model that account for more factors, using more reliable and fine-grained data.

value of ecosystem services, land planning, net value of ecosystem services, opportunity costs, cost of danger

doi: 10.1360/N972016-00027 